\title{
Conceptual Design of Fuel Cell Based Hybrid Unmanned Air Vehicle
}

\author{
Sinan Keiyinci ${ }^{* *}\left(\mathbb{D}\right.$, Kadir Aydın $^{1}$ \\ ${ }^{1}$ Çukurova University, Department of Automotive Engineering, Adana, Turkey
}

\begin{abstract}
Unmanned air vehicles (UAVs) are used successfully in many different fields mainly various military and civilian applications. Recently electric powered UAVs have become more preferable due to their better accessibility, cost, transportation and silence. However, the batteries used in electric UAVs still do not have enough energy density for long endurance flights. Due to the difficulty of using piston and gas turbine engines in small-sized UAVs, hydrogen fuel cells are seen as one of the considerable options to increase endurance and range. In this study, conceptual design of hybrid UAV including fuel cell, solar unit and battery is presented. Small, light and high endurance UAV was designed using aerodynamic calculations and minimum power requirement for cruise flight was determined. $100 \mathrm{~W}$ fuel cell produced by Horizon Fuel Cell Technologies and 3S, 5 Ah of battery were used for main power supplies, moreover solar cells to charge the battery were designed to mount on the surface of the wings. Also, a new power management system is designed for switching between the energy sources. As a result of this work, it is determined that fuel cells and solar units are the significant options which can increase the endurance of UAV up to 8 times depending on the design, solar flux, hydrogen capacity etc.
\end{abstract}

Keywords: UAV, propulsion, hybrid, fuel cell, solar cell, battery.

\section{INTRODUCTION}

An unmanned air vehicle (UAV) is a non-human air vehicle controlled autonomously by plugged microprocessors or telemetrically by an operator on the ground [1]. UAVs have received great interest in the last decades with many different usage missions for military and civilian areas [2]. As a result of this interest, many countries and institutions are making significant investments in this field. UAV market value is expected to reach $\$ 52.30$ billion by 2025 [3]. Recently interest in electric powered small UAVs has increased gradually because of its high efficiency, high reliability, low cost and reduced noise [4]. Considering issues such as insurance, license, maintenance, pilot license and flight permits, it is anticipated that small unmanned aerial vehicles will be used more in the future. Moreover, from a military point of view, it is known that the need for maneuverable UAVs of small sizes suitable for use in rugged terrain and residential areas is increasing. The primary problem encountered in small UAVs, especially in the field of imaging and intelligence, is the limit of the endurance and range. As the size of the air vehicle minimizes, the use of reciprocating and gas turbine engines becomes more difficult. On the other hand, battery systems using in electric UAVs cannot provide enough energy particularly in case of long endurance missions. Increa- sing the number of batteries is not a practical solution due to weight and space constraints. In order to offer a solution to this endurance and range problem of small UAVs, researchers have great interest in fuel cell-based hybrid propulsion systems for small UAVs since 2003 and several successful efforts have been practiced within this time period [4-15].

Fuel cells use $99.99 \%$ pure hydrogen to generate electrical energy via an electrochemical reaction between hydrogen from a source and oxygen in the air. At this point the need for a suitable hydrogen storage method emerges. Compressed hydrogen storage is the most common method for UAV applications however this method requires extremely high pressures. Lately, although the weight of compressed tanks has been significantly reduced with the new composite technology, the different methods such as liquid hydrogen and sodium borohydride continue to be explored $[7,8,13,16,17]$. In one of these studies, with the use of liquid hydrogen, exceeding 48 hours endurance was recorded [8]. In Table 1, some examples of fuel cell powered UAVs researches are presented.

In brief, nowadays the number of studies on long endurance UAVs by renewable and emission-free energy sources has increased significantly. One of the first options to achieve
* Corresponding author

Email: skeiyinci@cu.edu.tr
European Mechanical Science (2021), 5(1): 14-20

doi: https://doi.org/10.26701/ems.770407

Received: July 16, 2020

Accepted: October 12, 2020 
to increase endurance is fuel cell stacks that use hydrogen as fuel. Fuel cells $(1000 \mathrm{Wh} / \mathrm{kg})$ have about four or five times higher energy density than LiPo batteries (250 Wh/ $\mathrm{kg})[15,16]$ energy researches on aviation have turned to renewable energy sources providing electric propulsion. Fuel cells are one of the most popular sources of power for electric vehicles terms of being greener, more reliability, and higher efficiency. Among fuel cells, the most attractive option for flight is polymer electrolyte membrane fuel cells (PEMFC. When the researches on fuel cell powered UAVs are examined, it is predicted that some issues will be handled more in the near future; these are improving hybrid management system, reducing the weight, improving reliability and increasing their power density. In this regard, a novel design of fuel cell-based hybrid propulsion system of small UAV is presented in this study. Firstly, design of concept UAV is explained in details and then, an overview of the fuel cell, solar and battery system is given. Secondly, performance of hybrid propulsion system is evaluated experimentally and finally the endurance of battery and hybrid system are compared for the same model UAV.

\begin{tabular}{|c|c|c|c|c|c|c|}
\hline Organization & Year & $\begin{array}{l}\text { UAV } \\
\text { name }\end{array}$ & $\begin{array}{c}\text { Fuel Cell } \\
\text { Type }\end{array}$ & $\begin{array}{l}\text { Hydrogen } \\
\text { Storage }\end{array}$ & $\begin{array}{l}\text { Endu- } \\
\text { rance }\end{array}$ & Ref. \\
\hline AeroVironment & 2003 & Hornet & PEM & Liquid $\mathrm{H}_{2}$ & $15 \mathrm{~min}$ & [9] \\
\hline AeroVironment & 2008 & Puma & PEM & $\begin{array}{c}\text { Compressed } \\
\mathrm{H}_{2}\end{array}$ & $7 \mathrm{~h}$ & {$[10]$} \\
\hline $\begin{array}{c}\text { Korea Aerospace } \\
\text { Research Ins. }\end{array}$ & 2010 & EAV-1 & PEM & $\begin{array}{l}\text { Chemical } \\
\text { cartridge }\end{array}$ & $\begin{array}{c}4 \mathrm{~h} 30 \\
\min \end{array}$ & {$[11]$} \\
\hline $\begin{array}{c}\text { Korea Advanced } \\
\text { Inst of Science } \\
\text { and Tech. }\end{array}$ & 2011 & KAIST & PEM & $\mathrm{NaBH}_{4}$ & $\begin{array}{c}2 \mathrm{~h} 30 \\
\min \end{array}$ & {$[12]$} \\
\hline EnergyOr & 2011 & Faucon $\mathrm{H}_{2}$ & PEM & $\begin{array}{c}\text { Compressed } \\
\mathrm{H}_{2}\end{array}$ & $\begin{array}{c}10 \mathrm{~h} 04 \\
\min \end{array}$ & {$[13]$} \\
\hline $\begin{array}{c}\text { U.S. Naval Rese- } \\
\text { arch Lab }\end{array}$ & 2013 & Ion Tiger & PEM & $\begin{array}{l}\text { Cryogenic } \\
\text { liquid } \mathrm{H}_{2}\end{array}$ & $48 \mathrm{~h}$ & {$[14]$} \\
\hline
\end{tabular}

\section{MATERIAL AND METHOD}

\subsection{Conceptual Design}

Fuel cell-powered UAV model (Figure 1) is designed as fixed wing to perform surveillance mission. The main purpose of the novel UAV is to fly extended period of time and for this reason almost all flight phases is cruise stage. In this stage, the air vehicles consume minimum energy to equalize the drag force of the UAV. In connection with the limited power and relatively high weight of the fuel cell and solar system, model air vehicle was designed as a glider which can fly in cruise mode at a low power rating of about $50 \mathrm{~W}$.

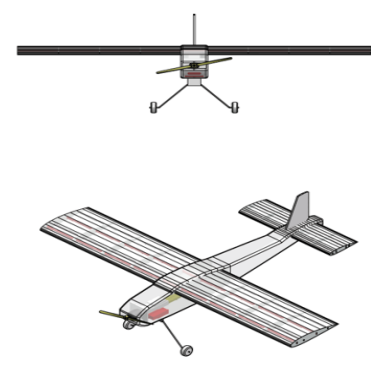

Figure 1. Conceptual UAV
To start the design of UAV, firstly empty weight has to be calculated. Since this air vehicle consists of three different power sources, this calculation should be done carefully. Weights fraction of the UAV system and the conceptual design parameters are given in Table 2 and Table 3 respectively. Figure 2 shows the weight distribution of the conceptual UAV.

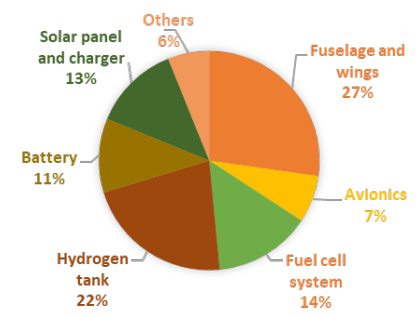

Figure 2. UAV's Weight Distribution

\begin{tabular}{|c|c|}
\hline \multicolumn{2}{|c|}{ Table 2. Weight Fraction of the UAV } \\
\hline Components & Weight $(\mathrm{g})$ \\
\hline Fuselage and wings & 900 \\
\hline Avionics & 230 \\
\hline Fuel cell system & 470 \\
\hline Hydrogen tank & 720 \\
\hline Battery & 360 \\
\hline Solar panel and charger & 420 \\
\hline Others & 200 \\
\hline Total weight & 3300 \\
\hline
\end{tabular}

Table 3. Specifications of Conceptual Design of the UAV

\begin{tabular}{|c|c|}
\hline UAV Design Specifications & Value \\
\hline Wingspan $(\mathrm{mm})$ & 2120 \\
\hline Wing area $\left(\mathrm{m}^{2}\right)$ & 0.638 \\
\hline Fuselage length $(\mathrm{mm})$ & 1100 \\
\hline Aspect Ratio $(\mathrm{AR})$ & 7.06 \\
\hline Empty mass $(\mathrm{kg})$ & 1.3 \\
\hline
\end{tabular}

Maximum take-off weight was assumed $3.3 \mathrm{~kg}$ according to first calculations. Wing span, aspect ratio and wing span values were calculated with the help of formulations in next chapter.

\subsection{UAV Power Requirement}

After estimating the approximate weight of UAV, the aerodynamic parameters and power requirement for cruise flight are to be calculated based on the related formulations. High lift/drag ratio and the appropriate surface for solar cells are the main concern to choose the optimum airfoil. As a result of research in literature and XFLR5 analysis, WE3.55 airfoil was determined.

In the horizontal $(\mathrm{x})$ direction, thrust force $\left(\mathrm{F}_{\mathrm{T}}\right)$ should be equal to the drag force $\left(F_{D}\right)$ according to the conservation of momentum, therefore the equation could be described as [17]:

$$
F_{X}=0=F_{T}-F_{D}
$$

and the drag force can be calculated as:

$$
F_{D}=\frac{1}{2} \rho A_{f}\left(C_{D}+C_{D, l i f t}\right)\left(V-V_{\text {wind }}\right)^{2}
$$


where

$\rho, A_{f}, C_{D}, C_{D, l i f t}$ are density of ambient air, the frontal area, the drag coefficient and induced drag coefficient of the wing, respectively. As

$V$ shows the velocity of the air vehicle, $V_{\text {wind }}$ expresses the wind velocity.

$$
C_{D, l i f t}=\frac{C_{L}^{2}}{\pi A R \cdot e_{O s}}
$$

It can be seen from eq. 3;

$C_{D, l i f t}$ can be found with using lift coefficient of airfoil, the aspect ratio which describes the square of the span divided by the wing area and

$e_{O s}$ (the Oswald efficiency number). Examining the literature of same type of fixed wings UAV, it can be seen that AR is around 6 and 9. In this study, there is also solar panel area factor to determine the wing span. As a result, AR is decided as 7.06 .

$$
\rho=\rho_{b}\left[\frac{T_{b}}{T_{b}+L_{b}\left(h+h_{a l t}-h_{b}\right)}\right]^{\left(1+\frac{g M_{\text {air }}}{R_{u} L_{b}}\right)}
$$

with

$\rho_{b}, T_{b}, L_{b}, g, M_{a i r}, R_{u}$ demonstrates density at sea level, the standard temperature, the temperature lapse rate, the standard gravitational constant, the molecular mass of Earth's air and the universal gas constant, respectively. In the eq. 4 ; h shows the location altitude, $h_{\text {alt }}$ the operating altitude and $h_{b}$ the height at the bottom layer.

$$
\begin{aligned}
& p=p_{b}\left[\frac{T_{b}}{T_{b}+L_{b}\left(h+h_{\text {alt }}-h_{b}\right)}\right]^{\left(1+\frac{g M_{\text {air }}}{R_{u} L_{b}}\right)} \\
& T=T_{b}+L_{b}\left(h+h_{\text {alt }}-h_{b}\right)
\end{aligned}
$$

Equation 5 and 6 show the pressure and temperature calculations at the operating altitude. Another equation from the Conservation of Momentum direction is the vertical (z) way as:

$$
F_{Z}=0=F_{L}-F_{G}
$$

The lift force formula can be calculated as:

$$
\begin{aligned}
& F_{L}=\frac{1}{2} \rho A_{p} C_{L}\left(V-V_{\text {wind }}\right)^{2} \\
& A_{p}=\frac{b^{2}}{A R}
\end{aligned}
$$

in this formula, $A_{p}$ describes the planform area and $\mathrm{b}$ is the wingspan of the air vehicle.

An air vehicle should produce enough lift equal to the gravitational force to keep itself at cruise flight. Therefore, the required minimum cruise speed was calculated according to eq.8. Model UAV parameters and values are given in Table
4 in detail.

Finally, required power of cruise flight of UAV can be calcu-

\begin{tabular}{|c|c|c|c|c|c|}
\hline Parameter & Variable & Value & Parameter & Variable & Value \\
\hline Mass & $\mathrm{m}$ & $3.3 \mathrm{~kg}$ & Wind speed & $V_{\text {wind }}$ & 0 \\
\hline Wingspan & $\mathrm{b}$ & $2.12 \mathrm{~m}$ & Altitude & $h$ & $314 \mathrm{~m}$ \\
\hline Speed & $V$ & $10 \mathrm{~m} / \mathrm{s}$ & $\begin{array}{l}\text { Bottom } \\
\text { Height }\end{array}$ & $h_{b}$ & $0 \mathrm{~m}$ \\
\hline $\begin{array}{l}\text { Operating } \\
\text { Altitude }\end{array}$ & $h_{\text {alt }}$ & $100 \mathrm{~m}$ & Static Pressure & $p_{b}$ & $101325 \mathrm{~Pa}$ \\
\hline Aspect Ratio & $A R$ & 7.06 & $\begin{array}{c}\text { Universal Gas } \\
\text { Constant }\end{array}$ & $\mathrm{R}_{\mathrm{u}}$ & $\begin{array}{c}8.3144598 \mathrm{~J} / \\
(\mathrm{mol} . \mathrm{K})\end{array}$ \\
\hline $\begin{array}{l}\text { Oswald } \\
\text { Efficiency }\end{array}$ & $e_{O S}$ & 0.84 & $\begin{array}{c}\text { Standard } \\
\text { Temperature }\end{array}$ & $T_{b}$ & $288.15 \mathrm{~K}$ \\
\hline $\begin{array}{l}\text { Drag Coeffi- } \\
\text { cient }\end{array}$ & & 0.0115 & $\begin{array}{c}\text { Density at Sea } \\
\text { Level }\end{array}$ & $\rho_{b}$ & $1.2250 \mathrm{~kg} / \mathrm{m}^{3}$ \\
\hline $\begin{array}{l}\text { Lift Coeffi- } \\
\text { cient }\end{array}$ & $C_{L}$ & 0.91 & $\begin{array}{l}\text { Temperature } \\
\text { Lapse Rate }\end{array}$ & $L_{b}$ & $-0.0065 \mathrm{~K} / \mathrm{m}$ \\
\hline Frontal Area & $A_{f}$ & 0.0466 & $\begin{array}{l}\text { Gravitational } \\
\text { Acceleration }\end{array}$ & $g$ & $9.80665 \mathrm{~m} / \mathrm{s}^{2}$ \\
\hline $\begin{array}{l}\text { Planform } \\
\text { Area }\end{array}$ & $A_{p}$ & 0.638 & $\begin{array}{c}\text { Molar Mass of } \\
\text { Earth's Air }\end{array}$ & $M_{\text {air }}$ & $\begin{array}{c}0.0289644 \mathrm{~kg} / \\
\mathrm{mol}\end{array}$ \\
\hline
\end{tabular}
lated as:

$$
\begin{aligned}
& P_{t}=T x V \\
& P_{t}=\frac{F_{t .}\left(V-V_{\text {wind }}\right)}{\eta_{p} \cdot \eta_{m} \cdot \eta_{c}}
\end{aligned}
$$

Where; $\eta_{p}, \eta_{m}, \eta_{c}$ propeller, motor and controller efficiencies, respectively.

\subsection{Horizon $\mathrm{H}-100$ Fuel Cell}

PEM type fuel cells are more suitable for small UAVs due to its low operating temperature range, small size and relatively higher efficiency [18]. Therefore, a PEMFC stack (Horizon Fuel Cell Technologies, H-100, $100 \mathrm{~W}$ ) was selected in this study as seen in Figure 3. H-100 fuel cell stack has 24 single cells with output power of $100 \mathrm{~W}$ at $12 \mathrm{~V}$ and $8.3 \mathrm{~A}$. This model is self-humidified type. Hydrogen was provided by a compressed hydrogen tank with full of $99.999 \%$ of pure $\mathrm{H}_{2}$. Table 5 shows the general specifications of $\mathrm{H}-100$ fuel cell system.

Table 5. Horizon H-100 Fuel Cell Stack Specifications

\begin{tabular}{|c|c|}
\hline Specifications & Value \\
\hline Number of cells & 20 \\
\hline Rated Power & $100 \mathrm{~W}(12 \mathrm{~V} @ 8.3 \mathrm{~A})$ \\
\hline Humidification & self-humidified \\
\hline Weight & 1290 grams \\
\hline $\mathrm{H}_{2}$ flow rate & $1.3 \mathrm{~L} / \mathrm{min}$ \\
\hline Peak Efficiency & $40 \% @ 12 \mathrm{~V}$ \\
\hline
\end{tabular}

A fuel cell controller is used to keep working the stack at nominal conditions and commands periodic short-circuiting and purging of the fuel cell stack. In general, fuel cell controller regulates the temperature management, air management (flow rate considerations) and purging (removing the water vapor from the cell). In addition, as a source of hydrogen, it was chosen to feed a total of 12 fuel cells from 
the hydrostik model which is the product of Horizon Company, each containing 10 liters.

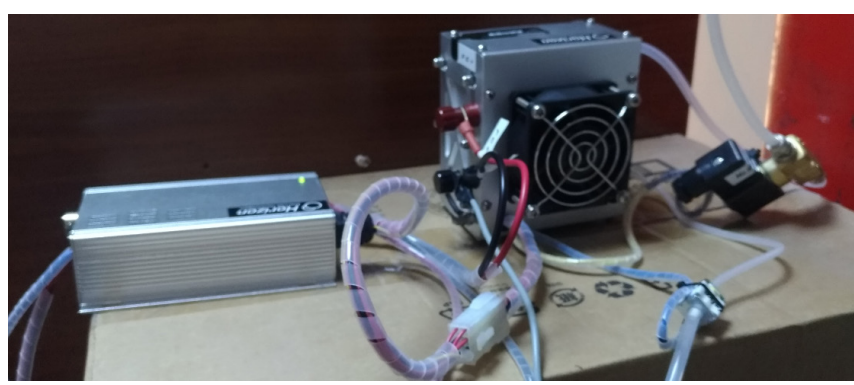

Figure 3. H-100 Fuel cell stack and controller

The polarization curves of H-100 PEM type fuel cell stack are presented in Figure 4. Maximum power can be obtained at $8.3 \mathrm{~A}, 12 \mathrm{~V}$ and $1.3 \mathrm{~L}$ hydrogen is required for this rated power of $100 \mathrm{~W}$.
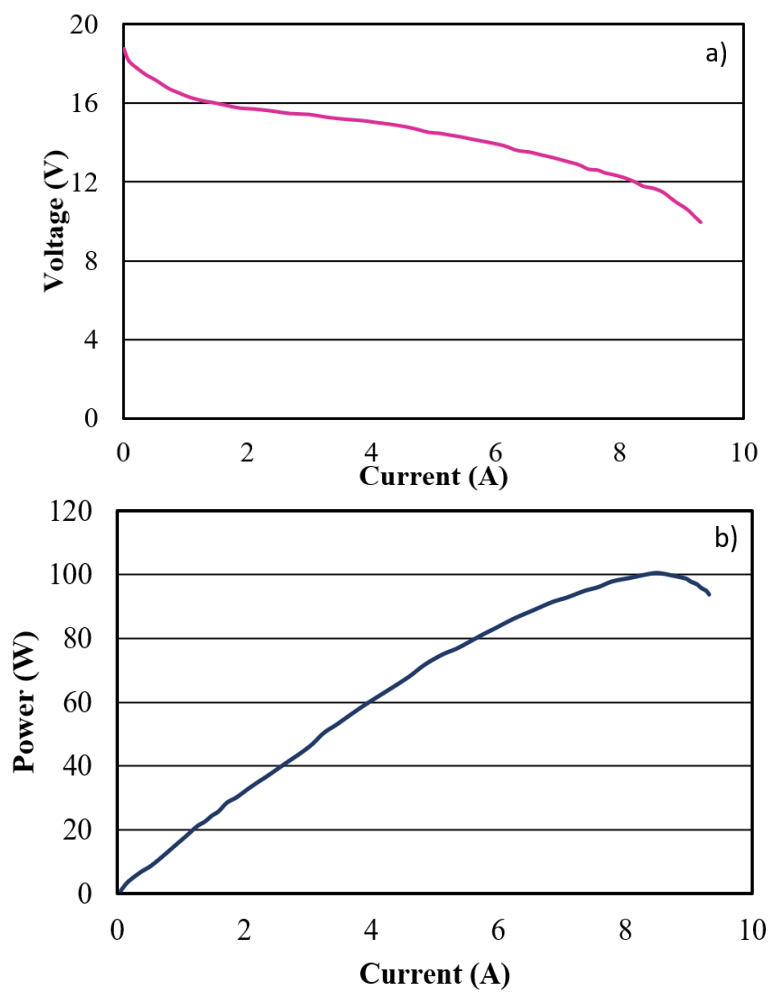

Figure 4. H-100 PEM fuel cell (a) voltage/current and (b) power/current graphs

$\mathrm{H}-100$ fuel cell is an old and cheap type model of PEMFC with the power density of $60 \mathrm{~W} / \mathrm{kg}$. For this reason, developed hybrid power pack system is tested on the laboratory, instead of on the UAVs. Nowadays, several commercial ultralight fuel cells are available on the market for air vehicles, which have the power density exceeds $400 \mathrm{~W} / \mathrm{kg}$.

\subsection{Solar System and Battery}

Fuel cells offer high energy density but they are inadequate in high power demands. Back-up system has to be used such as battery since take-off, climbing and maneuvering require high power ( $\mathrm{x} 3$ or $\mathrm{x} 4$ more than cruise phase). Lithium ion and lithium polymer (LiPo) batteries are most commonly used in small UAVs to boost power. In this design, $3 \mathrm{~S}$ (3 cells in series), $5000 \mathrm{mAh}, 25 \mathrm{C}$ LiPo battery was chosen to feed the load. While the nominal voltage of the battery is 11.1 $\mathrm{V}$, maximum voltage is $12.6 \mathrm{~V}$ at fully charged. There are mainly two reasons to be chosen $3 \mathrm{~S}$ model. Firstly, it could be hard to provide enough power during the high-power demands with $1 \mathrm{~S}$ or $2 \mathrm{~S}$. Secondly, using more than 3 series battery could need more voltage to charge and also it causes increasing wingspan and the weight of UAV.

In this hybrid design model, while fuel cell is active, solar panels on the wings start charging the battery. The Sunpower C-60 solar panel was chosen for its relatively high efficiency flexible photovoltaic model. C-60 has a length of $125 \times 125$ $\mathrm{mm}$ and $0.008 \mathrm{~kg}$ with rated voltage and current $0.57 \mathrm{~V}, 5.37$ A respectively. 30 solar cells are planned to mount of the UAV wings in series to charge LiPo battery. Figure 5 illustrates the battery and solar unit system.
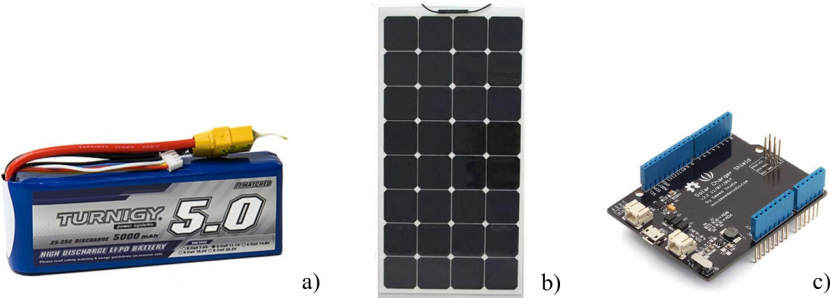

Figure 5. Lithium polymer battery (a), solar panel (b) and solar charger unit (c)

\subsection{Hybrid Propulsion System}

Battery, solar panel and fuel cell are the sources of the hybrid propulsion system of the model UAV. A novel hybrid management system was set up to control these three separate power units. A control card was integrated into the system with DC-DC relays that regulate the transitions. In this case, both fuel cell and solar panel are inactive while the battery voltage is full of charge $(12.61 \mathrm{~V})$. The test was started by setting DC load unit to $50 \mathrm{~W}$ which is the cruise power demand of UAV. When the battery voltage drops to nominal

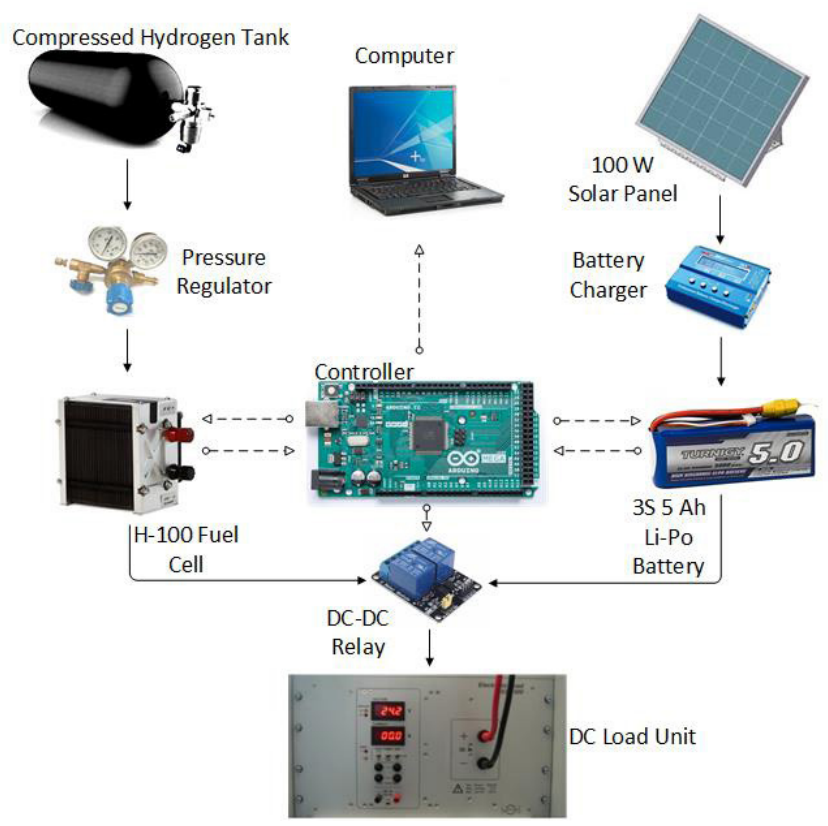

Figure 6. Hybrid propulsion ground test unit scheme 
value $(11.1 \mathrm{~V})$, the battery goes off and the fuel cell starts feeding the system with the help of the DC-DC relay. Solar panel starts to charge Li-Po battery while fuel cell is active until the fully charged status. After the battery voltage reaches the $12.61 \mathrm{~V}$, the relay stops the fuel cell power supply and the battery restarts to feed the load. This transformation continues as long as solar energy production continues and the compressed hydrogen tank becomes empty.

Hybrid propulsion system including experimental set up is illustrated in Figure 6.

Hydrogen tank consists of 200 bars of $\mathrm{H}_{2}$ at normal which is not appropriate for fuel cell stack. Thus, a pressure regulator was used to keep the pressure in the range of 0.45-0.55 bar. In addition to this, ALICAT mass flow meter was mounted between fuel cell stack and pressure regulator to measure the hydrogen consumption.

\section{RESULTS AND DISCUSSION}

In this study, the conceptual design of a small unmanned aircraft powered by three separate power units (battery, fuel cell and solar cell) was made. At this stage, some assumptions were made for certain required parameters according to the related literature. According to related formulations, 50 $\mathrm{W}$ power is required for cruise flight of model UAV. Since the small aircraft is modelled as a hand-launchable and also surveillance mission, more than $90 \%$ of flight time is cruise phase. For this reason, ground tests were applied with the 50 W of DC load.

After mathematical calculations of model UAV's requirements, hybrid system was tested successfully. Firstly, to compare the effect of fuel cell and solar panel, the load was fed by the battery only and calculated the time until the voltage dropped the nominal. Then, three cases were examined. At first, solar panel charges the battery permanently until the voltage of the battery falls below the nominal. Fuel cell system was not used for this case. In the second case, fuel cell system powers the load when the battery charge is dropped the nominal voltage and solar panel charges the battery only when fuel cell is active. For the last case, while the battery and fuel cell alternately continue to feed the load, the solar panel continuously charges the battery when the enough solar flux is available. The experiments were performed in November 2019, for this reason solar flux is relatively low (300-400 W/ $/ \mathrm{m}^{2}$ in clear weather). Figure 7 shows that while model UAV in cruise phase could fly about 64 minutes with only battery, after solar panel was activated, the endurance went up to 113 minutes. While battery, fuel cell and solar panel were run together, 393 and 517 minutes were measured depending on the status of the solar charge. The longest case as shown in Figure 8 has been finished after the solar flux is insufficient to charge the battery. Totally fuel cell was operated about 210 minutes to provide the load for the last case. According to measurement of hydrogen consumption by the flowmeter, approximately 120 liters hydrogen was used by fuel cell during this case.

Current and voltage parameters of solar, fuel cell and battery system were recorded to computer with the help of Ardunio card and current-voltage sensors. Figure 9 and 10 show conversion of the voltage and current values at the load of $50 \mathrm{~W}$. While the battery is on, the current of battery is increasing and the voltage is decreasing until the $10.5 \mathrm{~V}$. There is no considerable fluctuation in voltage and current for fuel cell except purging situation. Tests was started at $10 \mathrm{am}$ in a sunny day of November 2019, so when the solar flux decreased, the charging time of battery was extended as can be seen in Figure 7.

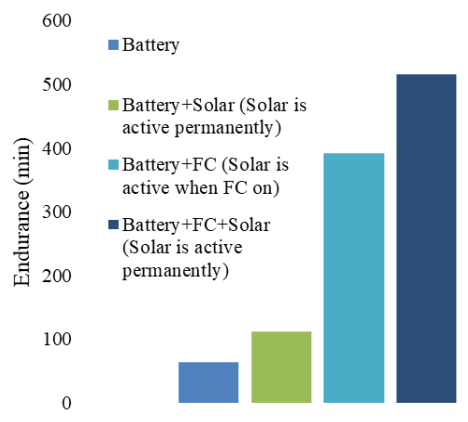

Figure 7. Estimated endurance time

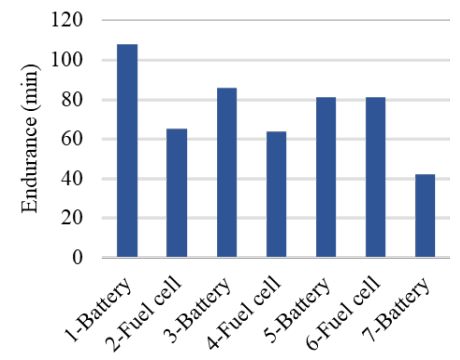

Figure 8. Endurance division for hybrid case

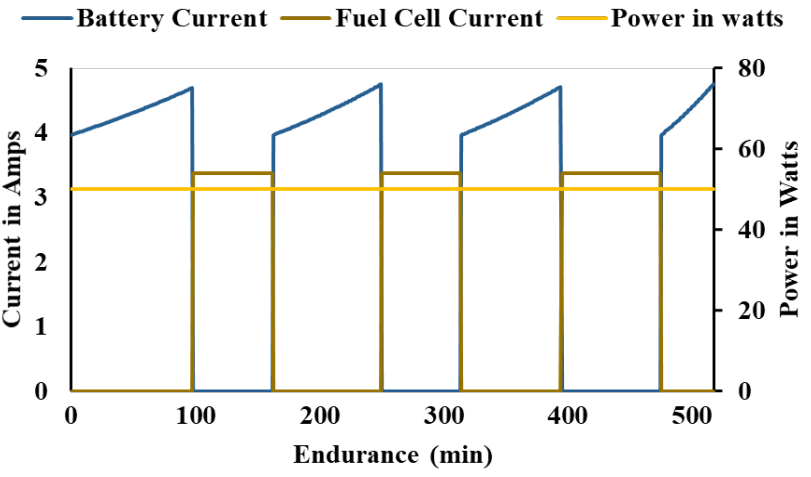

Figure 9. Current output vs time

Changing in power demands are ignored in this study which can be occurred at normal flight such as maneuvering, climbing and wind effects. These effects would cause in lower endurance of UAV. In particular, more power will be required to keep the aircraft at the same altitude, since the maneuver will cause the total drag force to increase. For this reason, more detailed study including the energy consumption of sub-parts and different flight phases is required to precisely predict the endurance of the fuel cell powered UAV. 


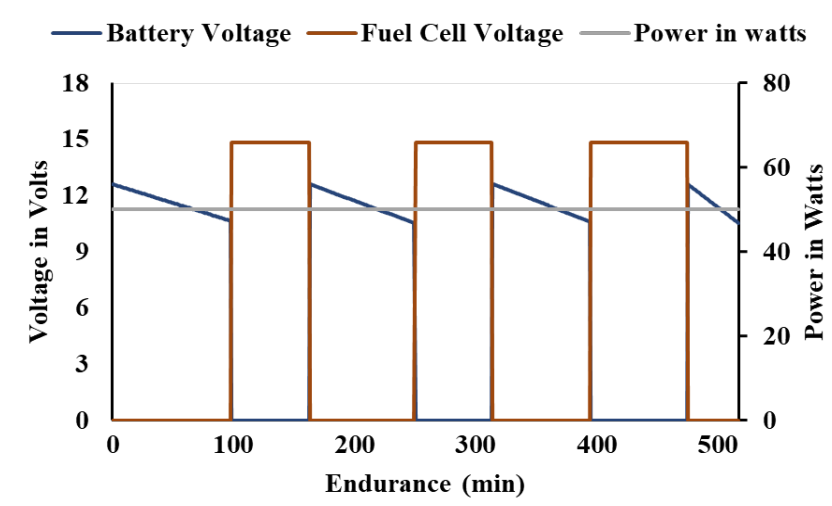

Figure 10. Voltage output vs time

\section{CONCLUSION}

Renewable energy sources offer high power and energy densities, lower costs, non-carbon emissions, more efficient power, lower acoustic and heat emissions, thus preventing detections and making tasks easier. Fuel cell systems which use hydrogen (one of the most preferred renewable energy source) as a fuel have recently been regarded as the primary candidate in increasing the endurance of air vehicles. The new ultralight fuel cell power and energy densities exceed $600 \mathrm{~W} / \mathrm{kg}, 2000 \mathrm{Wh} / \mathrm{kg}$ respectively, based on the commercial fuel cell producer's datasheets. Due to the difficulty of using piston and gas turbine engines in small-sized UAVs, hydrogen fuel cells could be seen as one of the considerable options to increase endurance and range however there are still many issues to be challenged such as hydrogen storage, initial investment cost (especially for very light models) and insufficiency in high power demands.

Before producing hybrid systems powered UAV, many factors and issues should be taken into account in the conceptual and preliminary design phases. In this study, a conceptual design of small UAV was presented and the ground tests of hybrid system with three components tests were performed. As a result, it has been determined that fuel cell powered UAVs with support of solar panels could reach more than eight times compared to battery powered UAVs for conceptual design phase.

\section{ACKNOWLEDGMENT}

The authors would like to thank the Çukurova University Scientific Research Project Coordination (FDK-2019-12071) for financial support to this project.

\section{REFERENCES}

[1] Liu, P., Chen, A.Y., Huang, Y.N., Han, J.Y., Lai, J.S., Kang, S.C., et al., (2014). A review of rotorcraft unmanned aerial vehicle (UAV) developments and applications in civil engineering. Smart Structures and Systems. 13(6): 1065-94. doi: 10.12989/sss.2014.13.6.1065.

[2] Arat, H.T., Sürer, M.G., (2019). Experimental investigation of fuel cell usage on an air Vehicle's hybrid propulsion system. International Journal of Hydrogen Energy. 5: 2-10. doi: 10.1016/j.jijhydene.2019.09.242
[3] Bozhinoski, D., Di Ruscio, D., Malavolta, I., Pelliccione, P., Crnkovic, I., (2019). Safety for mobile robotic system: A systematic mapping study from a software engineering perspective. Journal of Systems and Software. 151(2019): 150-79. doi: 10.1016/j.jss.2019.02.021.

[4] Gong, A., Verstraete, D., (2017). Design and bench test of a fuel-cell/ battery hybrid UAV propulsion system using metal hydride hydrogen storage. 53rd AIAA/SAE/ASEE Joint Propulsion Conference, 2017. (July): 1-12. doi: 10.2514/6.2017-4867.

[5] Kim, T., (2014). NaBH4 (sodium borohydride) hydrogen generator with a volume-exchange fuel tank for small unmanned aerial vehicles powered by a PEM (proton exchange membrane) fuel cell. Energy. 69: 721-7. doi: 10.1016/j.energy.2014.03.066.

[6] Kim, K., Kim, T., Lee, K., Kwon, S., (2011). Fuel cell system with sodium borohydride as hydrogen source for unmanned aerial vehicles. Journal of Power Sources. 196(21): 9069-75. doi: 10.1016/j.jpowsour.2011.01.038

[7] Gang, B.G., Kwon, S., (2018). Design of an energy management technique for high endurance unmanned aerial vehicles powered by fuel and solar cell systems. International Journal of Hydrogen Energy. 43(20): 9787-96. doi: 10.1016/j.jijhydene.2018.04.049.

[8] Swider-Lyons, K., Stroman, R.O., Gould, B.D., Rodgers, J.A., Mackrell, J., Schuette, M., et al., (2014). Hydrogen Fuel Cells for Small Unmanned Air Vehicles. ECS Transactions. 64(3): 963-72. doi: 10.1149/06403.0963ecst.

[9] McConnell, V.P., (2007). Military UAVs claiming the skies with fuel cell power. Fuel Cells Bulletin. 2007(12): 12-5. doi: 10.1016/S14642859(07)70438-8.

[10] Smeenk, R.M., Bruin, S.C., van Velthuysen, M.L.F., Verwaal, V.J., (2008). In Brief. Current Problems in Surgery. 45(8): 522-5. doi: 10.1067/j. cpsurg.2008.04.002.

[11] Lee, B., Park, P., Kim, K., Kwon, S., (2014). The flight test and power simulations of an UAV powered by solar cells, a fuel cell and batteries. Journal of Mechanical Science and Technology. 28(1): 399-405. doi: 10.1007/s12206-013-0936-7.

[12] Gong, A., Verstraete, D., (2017). Fuel cell propulsion in small fixedwing unmanned aerial vehicles: Current status and research needs. International Journal of Hydrogen Energy. 42(33): 21311-33. doi: 10.1016/j.j.jhydene.2017.06.148.

[13] Mobariz, K.N., Youssef, A.M., Abdel-Rahman, M., (2015). Long endurance hybrid fuel cell-battery powered UAV. World Journal of Modelling and Simulation. 11(1): 69-80.

[14] Stroman, R.O., Schuette, M.W., Swider-Lyons, K., Rodgers, J.A., Edwards, D.J., (2014). Liquid hydrogen fuel system design and demonstration in a small long endurance air vehicle. International Journal of Hydrogen Energy. 39(21): 11279-90. doi: 10.1016/j.jihydene.2014.05.065.

[15] Marta, A.C., Gamboa, P. V., (2013). Long Endurance Electric Uav for Civilian Surveillance Missions (September 2014).

[16] Arat, H.T., Sürer, M.G., Gökpinar, S., Aydin, K., (2020). Conceptual design analysis for a lightweight aircraft with a fuel cell hybrid propulsion system. Energy Sources, Part A: Recovery, Utilization and Environmental Effects. 00(00): 1-15. doi: 10.1080/15567036.2020.1773966.

[17] Depcik, C., Cassady, T., Collicott, B., Burugupally, S.P., Li, X., Alam, S.S., et al., (2020). Comparison of lithium ion Batteries, hydrogen fueled combustion Engines, and a hydrogen fuel cell in powering a small Unmanned Aerial Vehicle. Energy Conversion and Management. 207(November 2019): 112514. doi: 10.1016/j.enconman.2020.112514. 
[18] Tanç, B., Arat, H.T., Baltacıoğlu, E., Aydın, K., (2019). Overview of the next quarter century vision of hydrogen fuel cell electric vehicles. International Journal of Hydrogen Energy. 44(20): 10120-8. doi: 10.1016/j.jijhydene.2018.10.112. 